(c) American Dairy Science Association, 2004.

\title{
The Effect of Pasture Allowance and Supplementation on Feed Efficiency and Profitability of Dairy Systems ${ }^{\dagger}$
}

\author{
P. R. Tozer, F. Bargo, and L. D. Muller \\ Department of Dairy and Animal Science, \\ Pennsylvania State University, \\ University Park 16802
}

\section{ABSTRACT}

Partial budgeting was used to compare income over feed costs of high-yielding Holstein cows based on data from an experiment with 4 dietary treatments arranged in a $2 \times 2$ factorial. The factors were low $(25 \mathrm{~kg} \mathrm{DM} /$ cow per day) and high (40 kg DM/cow per day) pasture allowance (PA) and supplemental grain fed at $1 \mathrm{~kg} / 4$ $\mathrm{kg}$ of milk or no supplemental grain fed. The 4 treatments were low PA unsupplemented (LPAU), low PA concentrate supplementation (LPAC), high PA unsupplemented (HPAU), and high PA concentrate supplementation (HPAC). Two management systems were modeled. The first, a fixed herd size flexible rotation length model, and the second, a flexible herd size model where rotation length was fixed. The LPAC treatment yielded the highest income over feed costs, followed by the HPAC treatment. The treatment generating the lowest income was the HPAU system. The low PA systems generated more income than did the high PA systems for equivalent supplemental feeding strategies. The results also showed that feeding supplemental grain increased the income-over-feed costs compared with systems that did not feed supplemental grain. In most treatments, comparing the fixed herd against the flexible herd models, the flexible herd size model generated higher income due to the substitution of relatively low income per hectare of hay production for higher income from milk production. There were also differences in feed conversion efficiencies for milk production due to concentrate supplementation (1.04 unsupplemented vs. 1.21 supplemented), but PA did not affect the efficiency of milk production. Neither supplementation nor PA affected the feed conversion efficiency of milk fat yield. However, the efficiency of milk protein yield was affected by concentrate supplementation

Received November 6, 2003.

Accepted March 15, 2004.

Corresponding author: P. R. Tozer; e-mail: ptozer@agric.wa. gov.au.

$\dagger$ This research was undertaken as part of Multi-State Research Project NC-1119, Management Systems to Improve the Economic and Environmental Sustainability of Dairy Enterprises.
(0.028 unsupplemented vs. 0.034 supplemented) but not by pasture allowance.

(Key words: grazing, stocking rate, pasture allowance, concentrate supplementation)

Abbreviation key: $\mathbf{C S}=$ concentrate supplementation, HPA = high pasture allowance, HPAC = high pasture allowance concentrate supplemented, HPAU = high pasture allowance unsupplemented, IOFC = income over feed costs, LPA = low pasture allowance, LPAC = low pasture allowance concentrate supplemented, LPAU = low pasture allowance unsupplemented, $\mathbf{P A}=$ pasture allowance, $\mathbf{S R}=$ stocking rate .

\section{INTRODUCTION}

The inverse relationship between stocking rate (SR) and animal productivity in pasture-based systems is well understood (Mott, 1961; Leaver, 1985). As SR increases, per animal production decreases, but productivity per unit of area increases. However, the increase in productivity per unit of area is at a critical threshold that depends on the pastures and animals within the system, and past this threshold productivity per unit of area declines (Jones and Sandland, 1974). A different approach to grazing management is to use pasture allowance (PA) and evaluate the response of cows to different PA. Pasture allowance is measured as units of pasture offered, typically kilograms of DM/cow per day. Pasture allowance is comparable to SR because as PA increases SR decreases. Studies have examined the productivity of cows at different levels of pasture allowance rather than stocking rates (Peyraud et al., 1996; Dalley et al., 1999). These studies showed that, as pasture allowance increased, efficiency of grazing decreased when measured as the percentage of forage harvested from pasture available. This is a similar effect to the response of cows to decreasing SR.

Feeding grains as a concentrate supplement $(\mathbf{C S})$ to dairy cows that graze pastures has been shown to increase milk production (Leaver, 1985; Bargo et al., 2003). Overall, milk response to CS in high-producing dairy cows averaged $1 \mathrm{~kg}$ of milk/kg of concentrate (Bargo et al., 2003). Delaby et al. (2001) and Bargo et 
al. (2002) studied the combined effects of different PA and supplemental grain feeding. Feeding supplemental grain did increase the milk yield of cows in these studies. However, the results of the studies were mixed with respect to the interaction of $\mathrm{PA}$ and $\mathrm{CS}$ on milk production and milk component yields or composition. Delaby et al. (2001) reported no significant interaction effect on milk yield of PA and CS level, whereas Bargo et al. (2002) did report significant interaction effects on milk production.

The increased costs of feeding supplemental grains changes the relative profitability of the dairy system, and little research has examined the costs and benefits of feeding grain at different PA in dairy grazing systems. Fales et al. (1995) studied the effects of different SR on the production of pasture and profitability in a dairy system in the northeast United States. This research showed that the profitability of the system at high SR (4 cows/ha) was $\$ 1188 /$ ha greater than at low SR (2.5 cows/ha). In that study, all cows in the trial received supplemental grain at a rate of $1 \mathrm{~kg}$ of grain/ $4 \mathrm{~kg}$ of milk up to a limit of $9 \mathrm{~kg} / \mathrm{cow}$ per day.

Economic efficiency is defined as maximizing the returns (profitability) to a given set of fixed resources, typically land, labor, and capital (McInerney, 2000). In a dairy farm system, there are usually 2 fixed factors that are used to measure efficiency-land and capital (in the form of cows). The profitability or efficiency measure used, whether returns to land or cows, will depend on the scarcest resource to the producer. In New Zealand, profitability is typically measured in dollars per unit of land, as land is the most limiting resource in that production system (Holmes et al., 2002). However, the measure to use in the northeastern United States may be either land or cows, and the choice will be determined by the most limiting resource (Fales et al., 1995).

Feed conversion efficiency (FCE) is measured as the ratio of animal product yield or increase, milk or weight, to the amount of nutrient intake, where nutrient intake can be measured in energy, protein, or DM units (Hodgson, 1990) (i.e., $\mathrm{FCE}=\mathrm{kg}$ of product/kg nutrient intake). McMeekan (1956) concluded that dairy cows grazing at a low SR, or conversely at high pasture allowance (HPA), were more efficient in converting digestible organic matter into butterfat than cows grazing at high SR or low pasture allowance (LPA). The cows grazing at an LPA were more efficient at harvesting the material available but less efficient in converting the intake into butterfat (McMeekan, 1956). This led to a compromise in managing cows and SR in grazing systems, as a trade-off occurs between SR and FCE (McCall and Clark, 1999; Holmes et al., 2002). One factor that
McMeekan (1956) recognized was that the cows on trial were of low-producing genetic merit.

The objective in this research is to examine the impact of different PA and supplementation rates on per cow and per hectare profitability of a grazing system over the grazing period. A second objective is to compare the returns per hectare of 2 different stocking rates and pasture rotation strategies, a fixed SR with flexible rotation length, and flexible SR with fixed rotation length. The final objective of this study is to examine the FCE of high genetic merit cows under 2 PA and 2 CS feeding regimens.

\section{MATERIALS AND METHODS}

The general approach used in this analysis is a partial budget method, where returns are based on average milk and component prices under the current federal order system for the period January 2000 to July 2003. Costs were calculated for the variables that change under the different feeding systems for which data were available, hence the inclusion of experimental procedures and results in the following sections.

\section{Experimental Protocol}

A brief explanation of the experiment is provided here. A full description of the experiment with experimental procedures and results were published (Bargo et al., 2002). Twenty multiparous Holstein cows (BW, $631 \pm 71 \mathrm{~kg}$; milk yield, $45.8 \pm 6.6 \mathrm{~kg} / \mathrm{d}$; parity, $2.8 \pm$ 0.8; DIM, $101 \pm 35$ [mean \pm SD]) were blocked by DIM and randomly assigned to 4 dietary treatments within five $4 \times 4$ Latin squares with 21 -d periods. Cows were selected from The Pennsylvania State University Dairy Cattle Research and Education Center (University Park, PA), which averaged 11,436 kg of milk and 363 $\mathrm{kg}$ of protein per lactation. The first 2 periods were conducted during the spring, and the last 2 periods were conducted during the fall. Between the spring and fall periods, all cows were housed in a tie stall and fed a nutritionally balanced TMR because of the drought period that occurred during the summer, which decreased both quality of pasture fed and quantity of pasture available. With $75 \mathrm{~d}$ between periods 2 and 3, both stage of lactation and season (spring vs. fall) are confounded into the period effect.

The 4 dietary treatments were arranged in a $2 \times 2$ factorial. Factors evaluated were PA (LPA vs. HPA) and CS (unsupplemented [U] vs. supplemented [C]). The 4 dietary treatments resulted from the combination of the 2 levels of these 2 factors: low PA unsupplemented (LPAU), low PA concentrate supplementation (LPAC), high PA unsupplemented (HPAU), and high PA concentrate supplementation (HPAC). 
Pasture allowance targets were 25 and $40 \mathrm{~kg} \mathrm{DM} /$ cow per day measured to the ground level for the LPA and HPA treatments, respectively. To achieve these targets, pregrazing pasture mass was measured at 2$\mathrm{d}$ intervals and used to adjust sizes of paddocks and amount of pasture offered per cow on a daily basis (PA). Pregrazing pasture mass (kg DM/ha) was measured by cutting 10 quadrats $\left(0.124 \mathrm{~m}^{2} /\right.$ quadrat $)$ of pasture to ground level and drying at $55^{\circ} \mathrm{C}$ in a forced-air oven. A new paddock was constructed daily using a temporary polywire fence. A second polywire fence was used to prevent access to previously grazed areas. New paddocks were given to the cows at approximately $0700 \mathrm{~h}$ after each morning milking. Half of the cows $(n=10)$ grazed at LPA and half of the cows $(n=10)$ grazed at HPA divided by a temporary polywire. Pasture botanical composition was measured at the end of each of the 4 periods and averaged 50\% smooth bromegrass (Bromus inermis L.), 33\% orchardgrass (Dactylis glomerata L.), 7\% Kentucky bluegrass (Poa pratensis L.), and $10 \%$ weeds and dead material. Pasture was fertilized with $\mathrm{N}$ before the beginning of the first period (April 25) and the beginning of the third period (August 18) at a rate of $50 \mathrm{~kg}$ of N/ha.

Unsupplemented cows received no CS but were fed a mineral-vitamin mix at a rate of $1 \mathrm{~kg} / \mathrm{d}$ per cow to avoid mineral and vitamin deficiencies. The amount of concentrate offered per cow in the supplemented group was $1 \mathrm{~kg}$ of concentrate $/ 4 \mathrm{~kg}$ of milk at the beginning of period 1 using the pretrial milk production. An upper limit of $10 \mathrm{~kg} \mathrm{DM} / \mathrm{cow}$ per day was established for cows producing more than $40 \mathrm{~kg} / \mathrm{d}$ of milk. The amount of concentrate offered was adjusted before the beginning of period 3 using the milk production level before that period. Both the mineral-vitamin and the concentrate mixes were fed individually in 2 equal feedings after each milking. The ingredient composition of the mineral-vitamin and the concentrate mixes used for the unsupplemented and supplemented cows, respectively, are shown in Table 1. Cows were milked twice daily at 0600 and $1730 \mathrm{~h}$. The walking distance from pasture to the milking parlor averaged $0.9 \mathrm{~km}$ (range: 0.75 to $1.20 \mathrm{~km}$ ).

During each of the 421 -d periods, the first $10 \mathrm{~d}$ were used to adjust the cows to the different dietary treatments, and the last $11 \mathrm{~d}$ were used for experimental measures. Intake was estimated from d 15 to 19 of each period using $\mathrm{Cr}_{2} \mathrm{O}_{3}$ as an indigestible fecal marker, as described by Bargo et al. (2002). Milk production was recorded daily from d 11 to 21 during each period. Milk samples were collected 3 times on d 13, 16, and 19 and preserved with 2-bromo-2-nitropropane-1,3 diol. Milk fat, total protein, and true protein were analyzed by infrared spectrophotometry (Foss 605B Milk-Scan, Foss
Electric, Hillerød, Denmark) by the Pennsylvania DHIA milk-testing laboratory.

Individual FCE were calculated based on milk, fat, true protein production, and estimated pasture and total DMI. Dry matter intakes were used rather than energy, as the pasture energy values were assumed to be constant and energy values were not available. Also, as energy is expressed as a linear function of DMi.e., Mcal/kg DM-this assumption does not affect the underlying relationships, except for the scale of the FCE measure. The mixed model procedure of SAS (1999) was used to determine whether differences in efficiencies existed. The model included fixed effects for cow, period, and treatment, and cow within treatment was treated as a random variable within the model. Significance was declared at $P<0.05$, and when significant effects due to dietary treatments were detected, mean separation was conducted by the PDIFF option in SAS (1999). All means presented are least squares means.

\section{Pasture Growth}

Seasonal pasture growth data were extrapolated from Fales et al. (1995). These data were used because the study was carried out on the same type of pasture and at the same location as the experiment reported in this study. The growth rates used were: in spring, 62 and $68 \mathrm{~kg} \mathrm{DM} / \mathrm{ha}$ per day for the low and high SR treatments, respectively; in summer, $43 \mathrm{~kg} \mathrm{DM} / \mathrm{ha}$ per day for both SR; and 25 and $30 \mathrm{~kg} \mathrm{DM} / \mathrm{ha}$ per day for the low and high SR, respectively (Fales et al., 1995).

\section{Grazing System Management}

The grazing area of the farm is assumed to be 28 ha, divided into 28 1-ha paddocks. In the spring, when pasture growth is rapid, the number of paddocks grazed is reduced but dependent on the requirements of the cows. Any area not required for grazing will be assumed to be harvested for hay, which will be fed if feed shortages arise, or stored as conserved forage.

The management of the grazing system will reflect 2 different objectives. The first management system will use a fixed herd size of 60 cows and adapt the rotation length, hence land area, to provide sufficient pasture to supply the requirements of the cows. Given that land area will vary under the first system, the amount of land available for hay production will vary across feeding systems. The second system will assume a fixed rotation length of $14 \mathrm{~d}$ in spring and $28 \mathrm{~d}$ in summer and fall. Because of this, management system land area under each system is fixed at $28 \mathrm{ha}$, and in spring, 14 ha of land is not used for grazing and is harvested for hay production. In the second case, herd 
Table 1. Ingredients and costs of the mineral-vitamin mix and the concentrate used in the unsupplemented and supplemented pasture treatments.

\begin{tabular}{|c|c|c|c|c|c|}
\hline & $\begin{array}{l}\text { Vitamin } \\
\text { supplement } \\
\% \text { of DM }\end{array}$ & $\begin{array}{l}\text { Concentrate } \\
\text { supplement } \\
\% \text { of DM }\end{array}$ & $\$ / \mathrm{kg} \mathrm{DM}$ & $\begin{array}{l}\text { Cost/100 kg } \\
\text { vitamin } \\
\text { supplement }\end{array}$ & $\begin{array}{l}\text { Cost } / 100 \mathrm{~kg} \\
\text { concentrate }\end{array}$ \\
\hline Shelled corn & \multirow[t]{4}{*}{29.3} & 62.3 & 0.14 & \multirow[t]{4}{*}{4.19} & 8.90 \\
\hline Wheat middlings & & 10.4 & 0.16 & & 1.66 \\
\hline Barley & & 7.8 & 0.12 & & 0.97 \\
\hline Roasted soybeans & & 5.2 & 0.34 & & 1.75 \\
\hline Molasses & \multirow[t]{3}{*}{24.4} & 5.2 & 0.20 & \multirow[t]{3}{*}{4.95} & 1.05 \\
\hline Corn gluten meal & & 2.6 & 0.40 & & 1.03 \\
\hline Limestone & & 1.3 & 0.11 & & 0.14 \\
\hline Dicalcium phosphate & 19.5 & 2.1 & 0.55 & 10.75 & 1.16 \\
\hline Salt & 11.7 & 1.4 & 0.11 & 1.29 & 0.15 \\
\hline Magnesium oxide & 6.8 & 0.8 & 0.47 & 3.22 & 0.38 \\
\hline Dynamate & 4.9 & 0.6 & 0.43 & 2.08 & 0.26 \\
\hline Selenium premix $(0.06 \% \mathrm{Se})$ & 1.5 & 0.15 & 0.22 & 0.33 & 0.03 \\
\hline Trace mineral premix & 1.4 & 0.1 & 0.82 & 1.14 & 0.08 \\
\hline \multirow{2}{*}{ Vitamins A, D, E } & 0.5 & 0.05 & 0.93 & 0.46 & 0.05 \\
\hline & 100 & 100 & & $\$ 28.42$ & $\$ 17.62$ \\
\hline
\end{tabular}

size will vary across seasons and/or feeding systems, depending on the requirements of the cows in each season.

\section{Calculating Pasture Requirements}

The total amount of pasture required for a herd per day depends on how much is consumed, the efficiency of harvest, and the number of cows in the herd (Mayne et al., 2000). In this study, it is assumed that the dairy herd has 60 lactating cows. Bargo et al. (2002) reported an efficiency of pasture utilization of 62 and $42 \%$ for LPA and HPA, respectively.

To calculate the amount of pasture required to supply sufficient intake to the herd and/or the rotation length, the following method is used, which is adapted from Mayne et al. (2000):

(1) Pasture consumed per cow $(\mathrm{kg} \mathrm{DM} / \mathrm{cow}) \times$ number of cows = pasture required $(\mathrm{kg} \mathrm{DM})$.

(2) Pasture required ( $\mathrm{kg} \mathrm{DM}) \div$ efficiency of harvest $(\%)=$ total amount of pasture required $(\mathrm{kg} \mathrm{DM})$.

(3) Residual $(\mathrm{kg} \mathrm{DM})=$ total amount of pasture required $(\mathrm{kg} \mathrm{DM}) \times$ efficiency of harvest (\%).

(4) Rotation length $(\mathrm{d})=$ (total amount of pasture required $[\mathrm{kg} \mathrm{DM}]$ - residual after grazing $[\mathrm{kg} \mathrm{DM}]$ ) $\div$ growth rate of pasture $(\mathrm{kg} \mathrm{DM} / \mathrm{d})$

\section{Economic Information}

Given that a partial budget method of analysis is to be used, only prices and costs that vary across systems are needed. Therefore, as the grazing area is fixed, costs such as fencing and watering are not included in this analysis. Ration ingredients and prices for all feeds (Table 1) are averages from the feed price list (Ishler,
2003). These prices are representative costs for the feeds delivered on-farm in the northeast United States. Milk and milk component prices are derived from the Federal Order One Milk Marketing Administrator's Office and are averaged over the period from January 2000 through July 2003 (see Table 2) (Rasmussen, 2003). Pasture costs were derived from Elbehri and Ford (1995) and were estimated to be $\$ 0.0482 / \mathrm{kg}$ DM grown. The cost data of Elbehri and Ford (1995) are older than that of the output prices. However, those data were used because more contemporary data were not available. It is assumed in the costs for the individual ration ingredients, even if grown on-farm, that the costs cover all expenses incurred in growing, harvesting, and processing the commodity of interest. Sensitivity analysis was undertaken on milk prices and pasture and ration costs to determine the effect of changes in these major costs on the overall profitability of the grazing system.

Hay mowing, conditioning, raking, and baling costs were estimated from custom rates for Pennsylvania (Shimmin, 2003). The value of hay sold, $\$ 122.50 /$ tonne, is the average price for hay from 1997 to 2002 (PASS, 2003). It is assumed, based on Fales et al. (1995), that hay yield is approximately 3.2 tonne/ha for the HPA systems and 2.9 tonne/ha for the LPA systems. Although the hay may be used to provide supplemental forage for either the grazing or nongrazing seasons, the net return per hectare is included in this analysis to measure the opportunity costs and returns generated from the grazing area.

\section{RESULTS AND DISCUSSION}

Only statistical results that affect the economic outcome are presented. A complete explanation of other results is reported in Bargo et al. (2002). 
Table 2. Least squares means for daily milk, milk fat, and true protein yields and values, net milk income per cow; DMI of pasture, supplements and total intake; feed conversion efficiencies for milk, fat and true protein yields for cows on the 2 unsupplemented and 2 supplemented pasture allowance treatments. (Feed Conversion Efficiency = Product yield (kg per cow per d)/DMI (kg per cow per d)).

\begin{tabular}{|c|c|c|c|c|c|c|c|}
\hline & \multicolumn{4}{|c|}{ Feeding system $^{1}$} & \multicolumn{3}{|c|}{$P \leq^{2}$} \\
\hline & LPAU & LPAC & HPAU & HPAC & $\mathrm{CS}$ & PA & $\mathrm{CS} \times \mathrm{PA}$ \\
\hline \multicolumn{8}{|l|}{ Milk and milk component yields } \\
\hline Milk (kg/cow per day) & 19.10 & 29.70 & 22.20 & 29.90 & $<0.01$ & 0.04 & 0.03 \\
\hline Fat (kg/cow per day) & 0.74 & 0.96 & 0.84 & 0.98 & 0.01 & 0.08 & 0.01 \\
\hline True Protein (kg/cow per day) & 0.50 & 0.83 & 0.59 & 0.84 & $<0.01$ & 0.03 & 0.05 \\
\hline \multicolumn{8}{|l|}{ Milk component prices ${ }^{3}$} \\
\hline Fat $(\$ / \mathrm{kg})$ & 3.06 & 3.06 & 3.06 & & & & \\
\hline Protein $(\$ / \mathrm{kg})$ & 4.16 & 4.16 & 4.16 & & & & \\
\hline PPD $(\$ / 45.4 \mathrm{~kg})$ & 2.15 & 2.15 & 2.15 & & & & \\
\hline \multicolumn{8}{|l|}{ Milk and milk component revenue } \\
\hline Milk ( $\$ /$ cow per day) & 0.91 & 1.41 & 1.05 & 1.42 & & & \\
\hline Fat $(\$ /$ cow per day $)$ & 2.26 & 2.94 & 2.57 & 3.00 & & & \\
\hline Protein ( $\$ /$ cow per day) & 2.08 & 3.45 & 2.45 & 3.49 & & & \\
\hline Milk marketing costs $(\$$ per kg) & 0.02 & & & & & & \\
\hline Total marketing costs $(\$)$ & 0.36 & 0.56 & 0.42 & 0.56 & & & \\
\hline Total revenue per cow per d $(\$)$ & 4.89 & 7.24 & 5.66 & 7.34 & & & \\
\hline \multicolumn{8}{|l|}{$\mathrm{DM}$ intake, $\mathrm{kg} / \mathrm{d}$} \\
\hline Supplement & 0.80 & 8.60 & 0.70 & 8.70 & $<0.01$ & 0.56 & 0.36 \\
\hline Pasture & 17.50 & 15.50 & 20.50 & 16.10 & $<0.01$ & $<0.01$ & 0.01 \\
\hline Total & 18.30 & 24.10 & 21.20 & 24.80 & $<0.01$ & $<0.01$ & 0.01 \\
\hline \multicolumn{8}{|l|}{ Feed conversion efficiencies } \\
\hline Milk yield & 1.05 & 1.21 & 1.04 & 1.20 & $<0.01$ & 0.74 & 0.90 \\
\hline Fat yield & 0.04 & 0.04 & 0.04 & 0.04 & 0.96 & 0.72 & 0.85 \\
\hline True protein yield & 0.03 & 0.03 & 0.03 & 0.03 & $<0.01$ & 0.80 & 0.78 \\
\hline
\end{tabular}

\footnotetext{
${ }^{1} \mathrm{HPAC}=$ High pasture allowance supplemented; HPAU = high pasture allowance unsupplemented; LPAC = low pasture allowance supplemented; LPAU = low pasture allowance unsupplemented.

${ }^{2} \mathrm{CS}=$ Main effect of concentrate supplementation, $\mathrm{PA}=$ main effect of pasture allowance, $\mathrm{CS} \times \mathrm{PA}=$ concentrate supplementation by pasture allowance interaction.

${ }^{3}$ Source: Rasmussen (Various issues).
}

\section{Pasture and Concentrate Intake}

Dry matter intake of the mineral-vitamin mix averaged $0.7 \mathrm{~kg} / \mathrm{d}$, and DMI of concentrate averaged $8.6 \mathrm{~kg} /$ d. A significant interaction $(P<0.05)$ between PA and CS was found for pasture and total DMI (Table 2). Concentrate supplementation decreased $(P<0.05)$ pasture DMI at both PA. However, the decrease in pasture DMI was higher when cows grazed at high PA (4.4 vs. $2.0 \mathrm{~kg} \mathrm{DM} / \mathrm{d}$ ), indicating that the substitution rate was greater at high PA. There were significant differences in pasture and total DMI caused by the PA and CS treatments, as well as a significant $(P<0.05)$ interaction effect of both treatments (Table 2).

\section{Milk and Milk Component Production}

A significant $(P<0.05)$ interaction was found for milk production between PA and CS (Table 2). Supplementation increased milk production $(P<0.05)$. However, the increase was greater when cows grazed at low PA compared with high PA (10.6 vs. $7.7 \mathrm{~kg} / \mathrm{d})$. The PA $\times$ CS interaction for milk production is consistent with the interaction between PA and CS found for total DMI.
Because of this interaction, milk response to CS was greater when cows grazed at low PA compared with the high PA (1.36 vs. $0.96 \mathrm{~kg}$ of milk/ $\mathrm{kg}$ of concentrate). Supplementation increased $(P<0.05)$ milk fat yield at both PA (Table 2), principally due to the increased yield, as milk fat percentage declined $(P<0.05)$ with CS. Concentrate supplementation increased $(P<0.05)$ the true protein percentage in milk and the milk protein yield at both PA (Table 2). The increase in both total and true protein is likely related to the higher total energy intake in the supplemented cows (Bargo et al., 2002).

\section{Feed Conversion Efficiencies}

In all FCE comparisons, there are no significant interaction effects of PA and CS on FCE (Table 2). Beginning with milk yield, there were significant differences $(P<0.05)$ between efficiencies due to CS. However, there are no significant differences $(P>0.05)$ in $\mathrm{FCE}$ for milk due to PA or, alternatively, SR. A surprising result was that there is no difference due to either CS or PA on FCE for milk fat, which is in contrast to the results of McMeekan (1956). This suggests that cows 
Table 3. Differences in feed conversion efficiencies for milk, fat and true protein yields across the 4 experimental periods. (feed conversion efficiency $=$ product yield $(\mathrm{kg}$ per cow per $\mathrm{d}) / \mathrm{DMI}(\mathrm{kg}$ per cow per d)).

\begin{tabular}{llllll}
\hline & \multicolumn{5}{c}{ Experimental period } \\
\cline { 2 - 6 } Product & 1 & 2 & 3 & 4 & SEM \\
\hline Milk yield & $1.410^{\mathrm{a}}$ & $1.078^{\mathrm{b}}$ & $1.087^{\mathrm{b}}$ & $0.918^{\mathrm{c}}$ & 0.051 \\
Fat yield & $0.051^{\mathrm{a}}$ & $0.036^{\mathrm{b}}$ & $0.040^{\mathrm{c}}$ & $0.032^{\mathrm{b}}$ & 0.002 \\
True protein yield & $0.036^{\mathrm{a}}$ & $0.027^{\mathrm{b}}$ & $0.033^{\mathrm{c}}$ & $0.029^{\mathrm{b}}$ & 0.001 \\
\hline
\end{tabular}

${ }^{\mathrm{a}, \mathrm{b}, \mathrm{c}}$ Columns with different superscripts differ at $P<0.05$.

convert the total DMI, supplements, and pastures equally, and the conversion efficiency is not affected $(P$ $>0.05$ ) by supplement or pasture DMI. Finally, the FCE for true protein yield follows the same pattern as for milk yield-i.e., there were significant differences $(P<$ $0.05)$ due to $\mathrm{CS}$, but PA did not affect $(P>0.05)$ the FCE for true protein.

The effects of experimental period on FCE for milk, milk fat, and true protein yield are presented in Table 3. As mentioned earlier, the experimental periods were interrupted because of a dry summer, and cows in the experiment were fed a TMR over the summer, hence interpretation of the FCE for period 3 must be made with some care. The FCE for milk yield shows a significant $(P<0.05)$ declining linear trend over the length of the experiment, which is to be expected due to the cows being later in lactation and the partitioning of nutrients toward replenishing body reserves for the next lactation and away from milk production (NRC, 2001). The FCE for the milk component yields, milk fat, and true protein do not show any particular trends across periods, but there are differences $(P<0.05)$ between periods. For milk fat and true protein, the FCE in period one is significantly higher $(P<0.05)$ than all other periods. The FCE for milk fat and true protein are not different $(P>0.05)$ between periods 2 and 4 . However, the FCE for both components for period 3 is higher $(P<0.05)$ than the FCE in periods 2 and 4 . This may be in part due to the cows being fed a TMR before the beginning of period 3 , as cows were in higher body condition at the beginning of this period, hence there could be a confounding period effect.

\section{Pasture Availability and Rotation Lengths}

Fixed herd size. Using the pasture DMI from Table 2, and grazing efficiencies of 62 and $42 \%$ for LPA and HPA, the daily total amount of pasture required by the herd in each season is $1694,1500,2929$, and, $2300 \mathrm{~kg}$ DM for LPAU, LPAC, HPAU, and HPAC, respectively (Table 4). To achieve these levels of pasture production, the rotation intervals for each treatment in the spring are $15,14,20$, and $16 \mathrm{~d}$. In summer, the rotations are

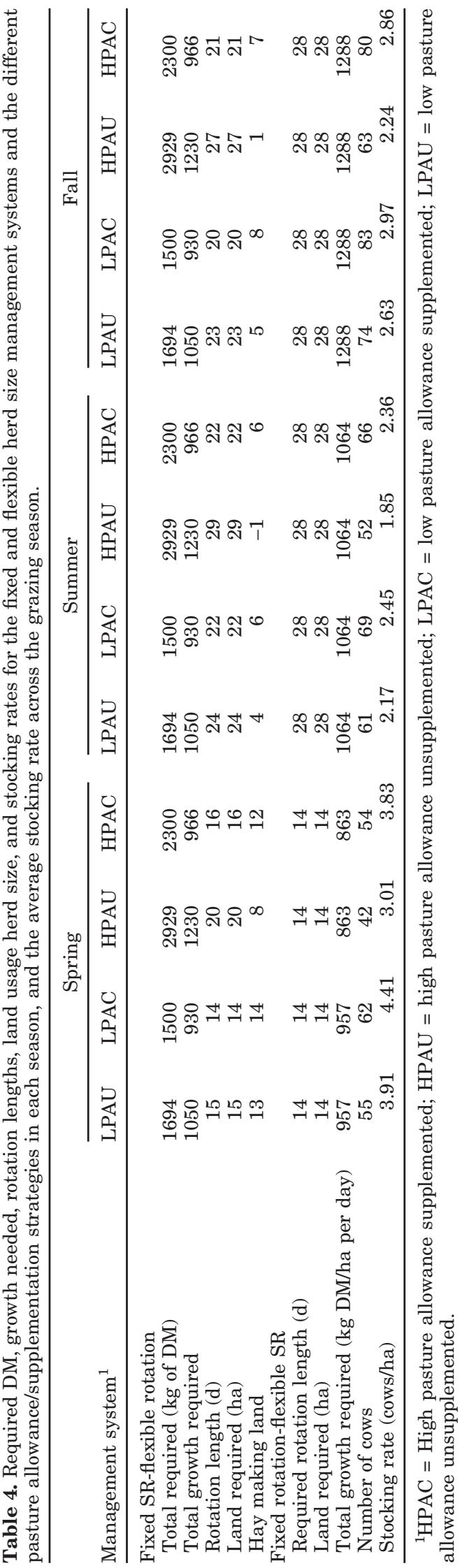

Journal of Dairy Science Vol. 87, No. 9, 2004 
Table 5. Income, costs, and returns per hectare and over the grazing season for each of the 4 grazing systems for fixed stocking rate and flexible rotation length.

\begin{tabular}{|c|c|c|c|c|}
\hline Feeding system ${ }^{1}$ & LPAU & LPAC & HPAU & HPAC \\
\hline Income $(\$ /$ cow per day $)$ & 4.89 & 7.24 & 5.66 & 7.34 \\
\hline \multicolumn{5}{|l|}{ Expenses } \\
\hline Rations (\$/cow per d) & 0.23 & 1.52 & 0.20 & 1.53 \\
\hline Pasture $(\$ /$ cow per d) & 1.36 & 1.21 & 2.35 & 1.85 \\
\hline Total feed expense ( $\$ /$ cow per $\mathrm{d})$ & 1.59 & 2.72 & 2.55 & 3.38 \\
\hline IOFC ( $\$$ cow per day) & 3.30 & 4.51 & 3.10 & 3.96 \\
\hline \multicolumn{5}{|c|}{ Grazing season returns } \\
\hline \multicolumn{5}{|c|}{ Fixed herd size and flexible rotation length } \\
\hline Stocking rate $($ cows/ha) & 2.88 & 3.25 & 2.39 & 3.04 \\
\hline Gross returns $(\$ /$ ha per $d)$ & 9.49 & 14.66 & 7.42 & 12.06 \\
\hline 168-d grazing season ( $\$ /$ ha) & 1,594 & 2,462 & 1,247 & 2,026 \\
\hline Average grazing area (ha) & 21 & 18 & 25 & 20 \\
\hline Returns to grazing area & $\$ 34,966$ & $\$ 47,842$ & $\$ 32,852$ & $\$ 41,938$ \\
\hline Hay returns & $\$ 5,554$ & $\$ 7,411$ & $\$ 2,525$ & $\$ 7,214$ \\
\hline Net returns over season (168 d) & $\$ 40,520$ & $\$ 55,253$ & $\$ 35,377$ & $\$ 49,152$ \\
\hline Average net return per ha & $\$ 1,447$ & $\$ 1,973$ & $\$ 1,263$ & $\$ 1,755$ \\
\hline \multicolumn{5}{|c|}{ Flexible herd size and fixed rotation length } \\
\hline Stocking rate $($ cows/ha) & 2.82 & 3.18 & 2.34 & 2.98 \\
\hline Gross returns $(\$ /$ ha per $\mathrm{d})$ & 9.29 & 14.35 & 7.26 & 11.80 \\
\hline 168-d grazing season $(\$ / \mathrm{ha})$ & 1,561 & 2,411 & 1,219 & 1,982 \\
\hline Returns to grazing area & $\$ 36,418$ & $\$ 56,259$ & $\$ 28,448$ & $\$ 46,240$ \\
\hline Hay returns & $\$ 3,634$ & $\$ 3,634$ & $\$ 4,062$ & $\$ 4,062$ \\
\hline Net returns over season (168-d) & $\$ 40,052$ & $\$ 59,892$ & $\$ 32,510$ & $\$ 50,302$ \\
\hline Average net return per ha & $\$ 1,430$ & $\$ 2,139$ & $\$ 1,161$ & $\$ 1,797$ \\
\hline $\begin{array}{l}\text { Difference in net returns } \\
\text { between systems }\end{array}$ & $-\$ 468$ & $\$ 4,639$ & $-\$ 2,867$ & $\$ 1,151$ \\
\hline
\end{tabular}

\footnotetext{
${ }^{1} \mathrm{HPAC}=$ High pasture allowance supplemented; HPAU = high pasture allowance unsupplemented; LPAC =
} low pasture allowance supplemented; LPAU = low pasture allowance unsupplemented.

$24,22,29$, and $22 \mathrm{~d}$ in length, and for the fall, the rotation lengths are $23,20,27$, and $21 \mathrm{~d}$. Given these rotation lengths and that the area grazed each day is $1 \mathrm{ha}$, the land requirements to sustain these rotation lengths are equivalent to the number of days in the rotation and, in all but 1 system, the land area is of sufficient size to sustain the rotation. The system that has insufficient land is the HPAU system in summer. To fill this shortfall of pasture, it would be necessary to feed either conserved hay over the $1 \mathrm{~d}$ of shortfall, or feed hay each day within the rotation to reduce the demands on the pasture. In either case, there is a cost incurred that will be analyzed later.

Flexible herd size. The herd size in this system varies from 42 to 83 cows, depending on the system and season (Table 4). In this management system, the amount of pasture required each period is determined by the fixed rotation lengths ( 14 or $28 \mathrm{~d}$ ), not herd size (Table 4). In this system, the SR is adapted to meet the supply of pasture available. Therefore, there are no periods in which it is necessary to provide conserved feed to supplement pasture growth.

However, the SR of both systems is identical. In the fixed herd size system, rotation length and land usage varies to suit pasture growth, whereas in the flexible system, herd size changes to meet pasture supply. In the context of this study and the economic analysis, we will focus on the fixed herd size system, as this is a more realistic situation for dairy producers, although a discussion of the flexible herd size results will be presented.

\section{Costs and Income for Each System}

Feed and pasture costs. Costs for the vitamin/mineral supplement for the unsupplemented cows was $\$ 0.23$ and $\$ 0.20$ per cow per day for the LPAU and HPAU treatments, respectively. The concentrate costs for cows on the LPAC and HPAC treatments were similar- $\$ 1.52$ and $\$ 1.53 /$ cow per day due to very similar intakes (Table 5).

The pasture costs for the different PA were different due to the differences in efficiency of harvest at the 2 PA. Given that the pasture costs $\$ 0.0482 / \mathrm{kg}$ DM to grow, the efficiency of harvest determines the cost of pasture to the system, as the total cost of the pasture must be covered by the enterprise utilizing it. For example, at a cost of $\$ 0.0482 / \mathrm{kg} \mathrm{DM}$ and an efficiency of $40 \%$, the true cost of pasture to the system is $0.0482 \div 0.4=$ $\$ 0.1205 / \mathrm{kg}$ of DM. Therefore, as the cows on the LPA treatments were more efficient at harvesting the pasture provided, the costs of pasture $(\$ / \mathrm{kg} \mathrm{DM})$ in those systems will be less than in the HPA systems. The effects of the efficiency of utilization are shown in the 
costs of pasture for each treatment. For the LPA treatments, the costs were $\$ 1.36$ and $\$ 1.21 /$ cow per day for LPAU and LPAC, respectively. Whereas the costs for the HPA treatments were $\$ 2.35$ and $\$ 1.85 /$ cow per day for the unsupplemented and supplemented treatments, respectively (Table 5). Total feed expenses for each system was $\$ 1.59, \$ 2.72, \$ 2.55$, and $\$ 3.38 /$ cow per day for LPAU, LPAC, HPAU, and HPAC, respectively (Table 4).

Milk income and net returns. The income per cow per day is reported in Table 2. As expected, the grazing systems that also provided supplemental grains yielded the highest milk income per cow per day. The effect of PA on income was less pronounced than the effect of supplementation. Cows on the LPA system yielded $\$ 0.77 /$ cow per day less for the unsupplemented cows compared with unsupplemented cows on the HPA treatment ( $\$ 4.89$ vs. $\$ 5.66$ ), and $\$ 0.10$ (LPAC) per cow per day less than cows on the HPAC treatment.

Calculating the income over feed costs (IOFC) for each system shows that the LPAC system yielded the highest IOFC of $\$ 4.51 /$ cow per day, $\$ 0.55 /$ cow per day more than the HPAC system (Table 5). The 2 unsupplemented systems generated $\$ 3.30$ and $\$ 3.10$ IOFC per cow per day for LPAU and HPAU, respectively.

The returns per grazed hectare per day, based on the SR calculated earlier from the pasture growth rates and fixed herd size assumption (Table 5), are $\$ 9.29$ (LPAU), \$14.35 (LPAC), \$7.26 (HPAU), and \$11.80 (HPAC). The differences in returns per hectare reflect the changes in SR caused by the demands for pasture under the 2 PA.

Estimating the returns per hectare over a 168-d grazing season under each production system from milk production are shown in Table 5. Also shown in Table 5 are the returns generated from the pasture area used by each system over the grazing season. These results show that providing supplements can increase returns over the 168-d grazing season by $\$ 14,733$ (LPA) or $\$ 13,774$ (HPA). Table 5 also shows that increasing the SR through lowering the PA, without supplementation, increased returns by approximately $\$ 5143$ over the grazing season. This is due to the more efficient utilization of the pasture grown at lower PA.

Hay income. One further factor needs to be added to the basic economic analysis of the different pasture systems, and that is the difference in hay making returns due to the differing demands on land under each management system. As discussed earlier, under the fixed herd size assumption, the amount of land required for grazing is adapted to match herd requirements, and that remaining land is used to make hay. Under these assumptions, the amount of land used to make hay is 22 (LPAU), 29 (LPAC), 9 (HPAU), and 25 ha (HPAC).
The net returns generated by the hay enterprise are approximately $\$ 260$ and $\$ 290 /$ ha for the LPA and HPA systems, respectively. Therefore, based on the areas harvested for hay, the net returns to the hay enterprise under each management system is $\$ 5554, \$ 7411$, $\$ 2525$, and $\$ 7214$ for the LPAU, LPAC, HPAU, and HPAC management systems, respectively.

Total returns over the grazing season and pasture area. Given the total returns from milk production and hay harvesting, and the land used for each system calculated previously, the most profitable grazing system is the LPAC, followed by the HPAC, LPAU, and HPAU. Averaging the returns over the total land area of 28 ha shows that increasing the SR lifts average return per hectare by $\$ 218$ over the grazing season for supplemented systems ( $\$ 1973$ vs. $\$ 1755$ ) and $\$ 184$ ( $\$ 1447$ vs. \$1263) for the unsupplemented pasture management system. These values differ from those of Fales et al. (1995) mostly because of the differences in SR between studies. Fales et al. (1995) reported an economic advantage of $\$ 578 /$ ha for a system with high SR of 4 cows/ha when compared with a medium SR of 3.2 cows/ha. In the current study, the range of SR is from 2.39 to 3.18 cows/ha for the fixed herd size model, which is much lower than those of Fales et al. (1995).

In most cases with a fixed herd size, the dairy producer cannot take full advantage of the land available for the most profitable enterprise-milk production. Therefore, the producer must use the pasture grown in another way, and typically this is to conserve forages for use in another season or during the nongrazing period. However, conserving forages or not fully utilizing the land available also gives the producer some protection against periods when pasture growth may be limited by unseasonably wet or dry periods that require use of conserved or purchased forages (Fales et al., 1995).

The alternative management situation, using a flexible stocking rate and a fixed rotation, generates more income than in the fixed herd size models in 2 of the 4 feeding strategies, because all available land is used to produce milk, which is a more profitable enterprise than hay production (Table 5). However, the herd size varies, depending on the PA and CS strategy and season, between 55 to 74 cows for the LPAU, 62 to 83 for LPAC, 42 to 63 for HPAU, and 54 to 80 for HPAC. The low average herd size for the HPAU system accounts for the lower profit generated by this system than under the fixed herd size model.

Two problems immediately arise with this type of management system. First, the producer needs to have access to the additional cows or decide how many cows to put on pasture or keep confined. Or, alternatively, the producer needs additional feeding facilities and feed 
while the pasture is unable to support a larger number of cows. In the analysis undertaken in this study, the costs of these additional resources were not measured and must be considered when comparing the 2 herd size strategies. Another problem that arises from the flexible herd size scenario is providing supplemental feed when pasture growth is retarded by extended dry or wet periods, as these will reduce the SR on pasture and require additional supplies of conserved or purchased feeds.

When deciding which feeding system to adopt, a dairy business would need to determine the investment required in each system. The investments for any grazing system are reasonably constant. The system requires fencing, watering, and feeding facilities and equipment. Also, in the northeastern United States, some form of housing is required. The type and size of housing chosen will depend on the system chosen. For example, with the fixed herd size situation, a producer knows for certain how many cows will require housing at any time. However, in the flexible system, the number of cows requiring housing will change with seasonal feeding patterns. Hence, the producer needs to select housing that is suitable for the system selected as well as the climate of the geographic area. The fixed herd system may also allow a producer to select a specific management strategy, such as seasonal grazing, to further reduce the requirements in capital investments. Under the flexible herd strategy, the number of cows being fed at different times will vary, therefore changing the labor requirements in different seasons. This may lead to further problems if these changes coincide with other events, such as cropping activities. However, in general, the capital investment in the alternatives discussed will typically be lower than for a confinement system. But the dairy producer also needs to be aware that the returns may not be as high as those from a confinement system (Tozer et al., 2003).

One problem that did arise in the original experiment was that of drought. This leads to the question regarding the sustainability of each system, both economic and biological. In the context of the models developed, by undertaking sensitivity analysis of the returns to reductions in grass growth caused by drought, the returns per hectare over the grazing season were not significantly affected by a reduction of either 10 or $20 \%$ in the pasture growth rates. Less than a $5 \%$ reduction in net income per hectare in each system was estimated. However, in the flexible management system, fewer cows were kept on pasture, and in the fixed stocking rate system, more of the grazing area was used for grazing. The problem that arises when analyzing drought within a simplistic basis such as this is that many biological factors need to be accounted for, such as the affect of the drought on pasture growth rates after the drought and pasture composition. Also, the animals may be adversely affected through loss of body condition.

In the context of the 4 different management scenarios, each will be affected differently. In the low-pasture allowance systems, cows graze more of the available pasture, therefore reducing the pasture mass from which regrowth occurs, potentially reducing the sustainability of these systems. In the systems that provide supplemental feeding, the cows can derive more of their nutrients from the supplements and may therefore remain in better condition over the drought. The affect on profitability of increased feed ingredient costs was also analyzed. With a drought reduction in growth rates of $20 \%$ and feed costs increasing by $10 \%$, the average reduction in returns per hectare was $5 \%$. The affect on the flexible herd size systems was higher than average at $7 \%$, and with the fixed herd systems, the affect was approximately $4 \%$.

Further sensitivity testing was undertaken to analyze the impact of changes in input and output prices on the profitability of each system. Reductions in the price of milk of $10 \%$ resulted in decreased returns per hectare of between 14 and 19\%, with the high-pasture allowance system being more affected than the low allowance system. The high allowance system is more affected than the low allowance system due to the lower stocking rate. A reduction of $20 \%$ in milk price caused a 29 to $37 \%$ decline in returns. Similar effects were observed when milk prices were increased by the same scale. Higher feed costs, pasture or ration, did not have the same effect on net returns. A 10\% increase in pasture costs yielded a reduction in net returns per hectare of between 2 and $7.3 \%$, with high pasture allowance systems being more affected as expected due to the higher pasture allowance and lower conversion efficiency of utilization. Elevated ration costs caused a relatively small reduction-less than 3\%-in returns only in systems where concentrates were fed. In general, all systems were more sensitive to changes in output prices than input costs. However, given the management skills needed in the flexible herd system and the sensitivity to prices shown, this system requires more input and is potentially more risky than the fixed herd system.

\section{CONCLUSIONS}

The objective of this research was to examine the impact of different PA and CS strategies on the profitability of the grazing system over the grazing season in the northeast United States. The results showed that low PA or high SR and feeding supplemental grain 
yielded the highest economic returns. The next most profitable system was a high PA system with supplemental grain fed, followed by a low PA system with no supplemental grain. A high PA system with no grain fed generated the lowest economic return. These results demonstrate the direct economic benefits of feeding supplemental grain in a grazing-based system over the grazing season. Indirect economic benefits from feeding grain, such as increased body condition, earlier return to positive energy balance, or better reproductive performance, are not included in this analysis but may increase even more the profitability of the grazing system. Also, it has been shown that lower PA, or higher SR, generate higher returns over the grazing season. Higher SR implies higher per hectare costs for other inputs, such as breeding costs and labor that must be deducted from the returns of each system. However, the differences in SR across systems are less than 1 cow/ ha. Therefore, it is unlikely that the costs of additional inputs would exceed the disparities in returns of the different feeding systems. Another indirect affect that needs to be considered when deciding whether to provide supplemental feeding is that of the nutrient balance on the farm because nitrogen and phosphorus will be imported in the ration ingredients. Hence, the producer confronted with nutrient management problems may be better off adjusting pasture allowance or providing a lower level of supplementation to the herd, as the nutrient management and/or environmental costs may outweigh the increased milk and revenue yields from supplemental feeding.

The final objective of this research was to evaluate the FCE of cows under different PA or SR. The results of this analysis suggest that SR, as previously thought, does not affect the FCE for milk and milk components. This has implications for managing grazing enterprises. Previously, it was thought that managing pasture production, pasture utilization, and FCE required compromises (McCall and Clark, 1999). This may not be the case. High genetic merit cows in grazing systems with high SR or low PA convert the pasture DMI into milk or milk components as efficiently as do high genetic merit cows in low SR systems.

\section{REFERENCES}

Bargo, F., L. D. Muller, J. E. Delahoy, and T. W. Cassidy. 2002. Milk responses to concentrate supplementation of high producing dairy cows grazing at two pasture allowances. J. Dairy Sci. 85:17771792 .
Bargo, F., L. D. Muller, E. S. Kolver, and J. E. Delahoy. 2003. Invited review: Production and digestion of supplemented dairy cows on pasture. J. Dairy Sci. 86:1-42.

Dalley, D. E., J. R. Roche, C. Grainger, and P. J. Moate. 1999. Dry matter intake, nutrient selection and milk production of dairy cows grazing rainfed perennial pastures at different herbage allowances. Aust. J. Exp. Agric. 39:923-931.

Delaby, L., J. L. Peyraud, and R. Delagarde. 2001. Effect of the level of concentrate supplementation, herbage allowance and milk yield at turn-out on the performance of dairy cows in mid lactation at grazing. Anim. Sci. 73:171-181.

Elbehri, A., and S. A. Ford. 1995. Economic analysis of major dairy forage systems in Pennsylvania: The role of intensive grazing. J. Prod. Agric. 4:449-507.

Fales, S. L., L. D. Muller, S. A. Ford, M. O’Sullivan, R. J. Hoover, L. A. Holden, L. E. Lanyon, and D. R. Buckmaster. 1995. Stocking rate affects production and profitability in a rotationally grazed pasture system. J. Prod. Agric. 8:88-96.

Hodgson, J. 1990. Grazing Management: Science into Practice. Longman Scientific and Technical, Harlow, UK.

Holmes, C., I. M. Brookes, D. J. Garrick, D. D. S. MacKenzie, T. J. Parkinson, and G. F. Wilson. 2002. Milk Production from Pasture: Principles and Practices. Massey University, Palmerston North, New Zealand.

Ishler, V. 2003. Feed Price List. http://www.das.psu.edu/teamdairy/ . Various issues. Accessed Sept. 23, 2003.

Jones, R. J., and R. L. Sandland. 1974. The relation between animal gain and stocking rate. J. Agric. Sci. (Camb). 83:335-342.

Leaver, J. D. 1985. Review article: Milk production from grazed temperate grassland. J. Dairy Res. 52:313-344.

Mayne, C. S., I. A. Wright, and G. E. J. Fisher. 2000. Grassland management under grazing and animal response. Pages 247291 in Grass: Its Production and Utilization. A. Hopkins, ed. Blackwell Science, Oxford, UK.

McCall, D. G., and D. A. Clark. 1999. Optimized dairy grazing systems in the northeast United States and New Zealand. II. Systems analysis. J. Dairy Sci. 82:1808-1816.

McInerney, J. P. 2000. Economic aspects of grassland production and utilization. Pages 394-428 in Grass: Its Production and Utilization. A. Hopkins, ed. Blackwell Science, Oxford, UK.

McMeekan, C. P. 1956. Grazing management and animal production. Pages 146-156 in Proc. of the 7th Int. Grassland Cong. Palmerston North, New Zealand.

Mott, G. O. 1961. Grazing pressure and the measurement of pasture production. Pages 606-611 in Proc. of the 8th Int. Grassland Cong. Reading, UK.

National Research Council (NRC). 2001. Nutrient requirements of dairy cattle. 7th revised edition. National Academic Press, Washington, DC.

PASS. (Pennsylvania Agricultural Statistics Service). 2003. Annual Summary 2002-2003. Pennsylvania Agricultural Statistics Service, Harrisburg, PA.

Peyraud, J. L., E. A. Cameron, M. H. Wade, and G. Lemaire. 1996. The effect of daily herbage allowance, herbage mass and animal factors upon herbage intake by grazing dairy cows. Ann. Zootech. 45:201-217.

Rasmussen, E. F. 2003. Pool Price Announcement. http://www. fmmone.com/Northeast_Order_Prices/NE_Prices_main_new. htm\#Uniform Various Issues. Accessed August 28, 2003.

SAS User's Guide. Statistics, Version 8.01 Edition. 1999. SAS Inst., Inc. Cary, NC.

Shimmin, S. W. 2003. Machinery Custom Rates, 2003. Page 100 in Pennsylvania Agricultural Statistics 2002-2003. Pennsylvania Agricultural Statistics Service, Harrisburg, PA.

Tozer, P. R., F. Bargo, and L. D. Muller. 2003. Economic analyses of feeding systems combining pasture and total mixed ration. J. Dairy Sci. 86:808-818. 